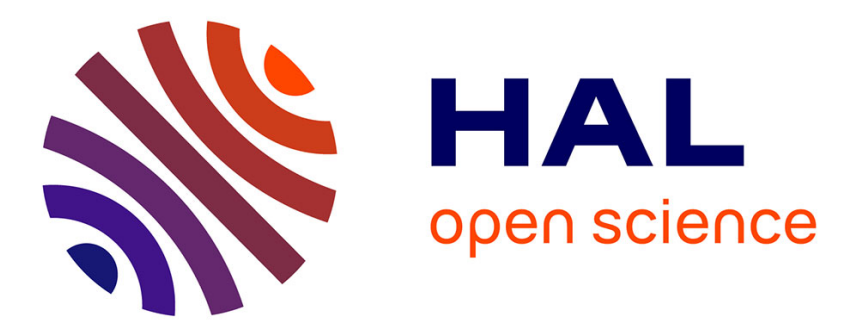

\title{
FLUXMANCHE radiotracers measurements: A contribution to the dynamics of the English Channel and North Sea
}

P. Guegueniat, P. Bailly Du Bois, J.C. Salomon, M. Masson, L. Cabioch

\section{- To cite this version:}

P. Guegueniat, P. Bailly Du Bois, J.C. Salomon, M. Masson, L. Cabioch. FLUXMANCHE radiotracers measurements: A contribution to the dynamics of the English Channel and North Sea. Journal of Marine Systems, 1995, 6 (5-6), pp.483-494. 10.1016/0924-7963(95)00019-L . hal-02433484

HAL Id: hal-02433484

https://hal-normandie-univ.archives-ouvertes.fr/hal-02433484

Submitted on 28 Aug 2020

HAL is a multi-disciplinary open access archive for the deposit and dissemination of scientific research documents, whether they are published or not. The documents may come from teaching and research institutions in France or abroad, or from public or private research centers.
L'archive ouverte pluridisciplinaire HAL, est destinée au dépôt et à la diffusion de documents scientifiques de niveau recherche, publiés ou non, émanant des établissements d'enseignement et de recherche français ou étrangers, des laboratoires publics ou privés. 
MAST-52: 21 Décembre 1993

MAST-53: 21 Décembre 1993

FLUXMANCHE RADIOTRACERS MEASUREMENTS : A CONTRIBUTION TO THE DYNAMICS OF THE ENGLISH CHANNEL AND NORTH SEA

P. Guegueniat ${ }^{\mathrm{a}}$, P. Bailly du Bois ${ }^{\mathrm{a}}$, J.C. Salomon ${ }^{\mathrm{b}}$, M Masson ${ }^{\mathrm{a}}$, L. Cabioch ${ }^{\mathrm{c}}$

a : IPSN-CEA, Laboratoire de Radioécologie Marine, 50444 Beaumont Hague, France

b : IFREMER, BP 70, 29280 Plouzané, France

c : Station Biologique, BP 74, 29680 Roscoff

Correspondence:

P. Guéguéniat

Tlf direct: $\quad 3303$

6822

de Radioécologie Marine

Laboratoire

Tlf secretary 33036823 
IPSN-CEA

6919

FAX: (33) 3303

50444 Beaumont-Hague Cedex

France 
FLUXMANCHE RADIOTRACERS MEASUREMENTS : A CONTRIBUTION TO THE DYNAMICS OF THE ENGLISH CHANNEL AND NORTH SEA

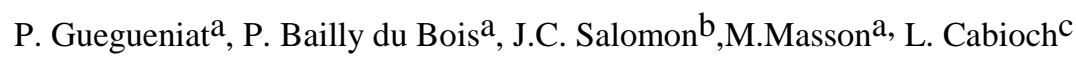

\begin{abstract}
From 1986 to $1992,{ }^{125} \mathrm{Sb}$ released by La Hague Fuel Reprocessing Plant, was used to study the transfert of waters from mid-Channel areas towards the Dover Strait. Since 1990 these investigations have been part of MAST 53 FLUXMANCHE programme with repeated measurements on the Dover Strait transect. The discussion of the results will take into consideration new informations given by the hydrodynamic model elaborated in the frame of FLUXMANCHE: knowledge of the monthly fluxes of water in the Strait of Dover and simulation of the ${ }^{125} \mathrm{Sb}$ activities, week by week, in the waters flowing in this aera. It is shown that solubles radionuclides introduced into the central Channel are transfered towards the Dover Strait in a time which varies between 4 and 7 months, depending on the route taken.
\end{abstract}

\title{
1. Introduction
}

The English Channel is an area of transfert of dissolved and particulate material to the North Sea; it is characterised dominantly by tidal hydrodynamics and meteorological forcing. The tidal regime influences this general water flow from the Western Shelf to the North Sea and the dynamics of its interface with estuarine and coastal waters. 
The overall objective of FLUXMANCHE during the MAST I phase is to obtain, through an interdisciplinary approach, a better knowledge of the dynamics of the eastern Channel and the exports of water and associated materials to the North Sea.

The radiotracer measurements carried out in the framework of FLUXMANCHE in the eastern Channel and Dover Strait are part of a broader approach to the oceanography of the North-Western continental shelf in terms of space/time long range observations and interdisciplinary predictive integration.

Artificial radionuclides present as soluble species in seawater are of particular interest, specially when they have a conservative behaviour. It is also possible to measure them at very low levels of activity. Given a knowledge of the source-terms, the movements of labelled water masses can be monitored by means of these tracers.

Most of the measurements have been concentrated on ${ }^{125} \mathrm{Sb}$, which is a specifie marker of discharges from La Hague, conservative within the water masses, absent in the background of sea water and present only in small amounts in the Tchernobyl fallout. Since 1982, about 2500 analyses of seawater have been perfomed in the North-West European waters. During this period, (1987-1993) the monthly releases have decreased from 21.000 GBq/y (January 1987) to $250 \mathrm{GBq} / \mathrm{y}$ (March 1993).

Since 1991, these investigations have been part of MAST projects closely linked in that field : MAST 53 "FLUXMANCHE" and MAST 52 "Studies on the transport of coastal water from the English Channel to the Baltic Sea using radioactive tracers". This association ensures the identification of the pathways and the estimation of fluxes on a broad geographical scale, allowing a better understanding of the previous 
measurements. Moreover, through the intensive field measurements carried out in these two projects, it has been possible to undertake an overall reinterpretation of some previous data sets on the appropriate space/time scales.

Other conservative radionuclides have been measured in water in the frame of MAST 52:

- ${ }^{137} \mathrm{Cs}$, a marker of discharges from Sellafield

- ${ }^{90} \mathrm{Sr}$ and ${ }^{99} \mathrm{Tc}$

The objective of this work is to make a synthesis of the FLUXMANCHE results which can be useful for North Sea programm.

\section{Analyticals Methods and Sampling}

2.1. Methods

Activities of ${ }^{125} \mathrm{Sb}$ were measured by gamma-ray spectrometry after a single or a double extraction with Manganese dioxyde at pH 3.5 (GANDON R., GUEGUENIAT P. ; 1992)

2.2 Samplings since September 1990

Major cruises in the Channel :

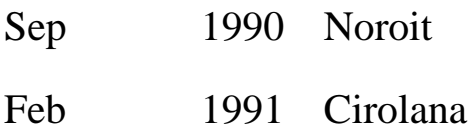


1991 Suroit

Nov 1991 Alexander Humboldt

Jan 1992 Cirolana

Repeated measurements on the Dover Strait transect

\begin{tabular}{|c|c|c|c|}
\hline Sep & 1990 & Dover Strait & Noroit \\
\hline Oct & 1990 & Dover Strait & Pluteus II, Noroit \\
\hline Oct & 1990 & Dover Strait & Noroit \\
\hline Nov & 1990 & Dover Strait & Thalia \\
\hline Dec & 1990 & Dover Strait & Pluteus II \\
\hline Jan & 1991 & Dover Strait & Pluteus II \\
\hline Mar & 1991 & Dover Strait & Pluteus II \\
\hline June & 1991 & Dover Strait & Pluteus II \\
\hline July & 1991 & Dover Strait & Suroit \\
\hline Aug & 1991 & Dover Strait & Suroit \\
\hline Sep & 1991 & Dover Strait & Sepia II \\
\hline Oct & 1991 & Dover Strait & Sepia II \\
\hline Nov & 1991 & Dover Strait & Pluteus II \\
\hline \multicolumn{4}{|c|}{ Additional samplings } \\
\hline Dec & 1991 & \multicolumn{2}{|c|}{ French coastline } \\
\hline Jan & 1992 & $"$ & \\
\hline $\mathrm{Feb}$ & 1992 & $"$ & \\
\hline Apr & 1992 & $"$ & \\
\hline May & 1992 & $"$ & \\
\hline June & 1992 & $"$ & \\
\hline Sep & 1992 & $"$ & \\
\hline Oct & 1992 & $"$ & \\
\hline
\end{tabular}


Nov

Dec

The sampling programme for the transects was devised to collect samples of sea water on a monthly basis, if possible, at the 6 standard FLUXMANCHE sites (1-6, sea fig. 1).

\section{$\underline{\text { La Hague releases }}$}

The monthly ${ }^{125} \mathrm{Sb}$ releases from la Hague fuel reprocessing plant between 1982 and 1992 are given fig. 2.

The main events of the evolution in the releases have been a relatively important increase during winter 1986-1987, with a maximun in December (20500 GBq), January (22000 GBq), February (20000 GBq), followed by a general irregular decrease until December 1991 (260 GBq). The study of the transfer of the winter 1986-1987 La Hague signal through the Channel and the North Sea, has given a good opportunity to estimate broadscale transit times and to compare them with model outputs and other measurements in the framework of MAST 52 and MAST 53 FLUXMANCHE. The results FLUXMANCHE monthly stations in the Strait of Dover have also been used for such estimates, using the opportunity of a temporary increase of the release in April-May 1991.

The monthly releases of ${ }^{90} \mathrm{Sr}$ and ${ }^{137} \mathrm{Cs}$ are given on figures 3 and 4 for interpretation of results obtained in North Sea. 


\section{Results}

\subsection{English Channel}

The data shown on figure 5 represents a typical distribution of ${ }^{125} \mathrm{Sb}$ over the entire Channel that was observed in June 1986 (GUEGUENIAT and al., 1988). Under the influence of residual tidal currents, the discharged radionuclides are carried off mostly to the east and are little dispersed. A banded structure is apparent, parallel to the current direction, which displays strongly decreasing activities away from the French coast. To a certain extent, the southern coast of England is protected by this drift effect; as a result, the measured activities $\left(\mathrm{Bq} / \mathrm{m}^{3}\right)$ near the English coast $(0-12)$ are less than those obtained in the Baie of Seine and off the Pays de Caux - Nord Pas de Calais (30-80). In January 1992 the level of activity has decreased of a factor 10 (see fig. 6).

First simulations done later using the 2D advection-dispersion model (SALOMON and al., 1991) for average meteorological conditions (fig. 7) are consistent with this type of field distribution. This simulation refers to a theoretical scenario: starting from a zero situation in the Channel, a sudden and permanent discharge of $10000 \mathrm{GBq} /$ month of ${ }^{125} \mathrm{Sb}$ is supposed to take place indefinitely. The tide is an average one and the wind blows from the South West, inducing a stress of $\mathrm{O}, \mathrm{O} 74 \mathrm{Newton} / \mathrm{m}$. Results are presented in fig 7 for different stages: 3, 6 and 12 months. Flow in the Strait of Dover is $119000 \mathrm{~m}^{3} / \mathrm{s}$. The resulting situation may be compared to experimental indications in figure 6. Comparisons seem very good. 


\subsection{Strait of Dover}

\subsubsection{Prior to FLUXMANCHE}

Transects were repeatedly sampled in the Boulogne-Folkestone-DoverCap Gris Nez quadrangle over the period 1987-1990. A manisfestation of the pulse of radioactivity of winter 1986-1987 is observed at the begining of April 1987 in the central waters but without measurements in March and May, it is not possible to know whether the maximum value recorded corresponds or not to the maximum effect of the pulse observed in january. Therefore, estimating a transit time from this observation is rather imprecise and leads to values between two and four months. In the French coastal waters the maximum value was recorded in July 1987, corresponding to a transit time around seven months (GUEGUENIAT and al., 1993). It is proposed that waters passing through the Strait of Dover during April 1987 bear the trace of industrial discharges released at different moments. Coastal waters show the effects of low discharges that originated between August and November 1986, whereas offshore waters are influenced by more recent relatively high discharges (December 1986 to February 1987, see fig. 8). In July 1987, the situation is reversed. The resulting evolution may be compared to the simulation of the permanent discharge at La Hague (see fig 7) after 3 and 6 months. Comparison seem very good: the first manifestation of the release is observed in the central waters of Strait of Dover.

\subsubsection{During FLUXMANCHE}


The variations of the concentrations of ${ }^{125} \mathrm{Sb}$ in the Strait of Dover measured at the six sampling stations on the transect from september 1990 to March 1991 are represented on figure 9.

The discussion of these results will take into consideration new informations given by the hydrodynamic model elaborated in the frame of FLUXMANCHE (SALOMON, BRETON; in press.): knowledge of the monthly fluxes of water in the Straits of Dover.

The flow in the central pathway of the eastern Channel is strongly dependent upon meteorological forcing. Generally oriented towards the North Sea, it may vary from a factor 1 to 10 or 20 at a montly scale and even be reversed under north to easterly wind conditions. For example, calculated in $10^{3} \mathrm{~m}^{3} \cdot \mathrm{s}^{-1}$, the flux varied between 8 in February 1988 and more than 130 in January and March of the same year (SALOMON and al., in press.). As most of the dilution of releases of the La Hague treatment plant takes place in the neighbouring area, the concentrations resulting from a constant release may be highly variable in time, in relation to the local residual flow to the general flow towards the North Sea. Therefore, as a first approximate, the ratio of the mean monthly release flux to the main water flux through the Strait of Dover, at the same time, has the dimension of an initial concentration value, which may be compared with the measurements of concentrations in the Strait of Dover in order to improve the estimates of transit times.

The monthly ratios of the releases to the water fluxes, of the same month, through the Strait of Dover have been calculated for 1991 and represented on figure 10 as percentages of the maximum ratio obtained. Due to the variations of the flow through the Strait of Dover, this maximum (May), considered as representative of the maximum concentration at the beginning of the transit near la Hague, does not correspond in time to the 
maximum monthly release (also percentages of the maximum value) which is observed in April.

\section{Transit time along the central pathway of the eastern Channel}

In the Strait of Dover, the average values of ${ }^{12} \mathrm{Sb}$ activities for stations 1 to 5 , considered as representative of waters issued from the direct central pathway of the Eastern Channel, are represented on figure 11 for the year 1991 The maximum activity has been observed in September (measurement on Sept. 1st). Without measurement in August, the transit time may be estimed to around 3 or 4 months, comparatively to the initial normalized peak in the La Hague area (continuous line). The results of the 2D advection-dispersion model taking account the daily releases at La Hague (fig. 12) indicates that the maximum value of $125 \mathrm{Sb}$ activity in the central waters of the Strait of Dover is observed betwween 23 of August and 19 of September: the transit time is around 4 months. There is a good quantitative agreement between the model and the results of the monthly FLUXMANCHE measurements.

By another way a repeated series of oceanographic campaings (7 between 1987 and 1992) in the North Sea has enabled a quantitative investigation of the dispersal of radionuclides between the Straits of Dover and the Skagerrak in the frame of MAST 52C programm (BAILLY DU BOIS and al., this volume). On the basis of the $125 \mathrm{Sb}$ and $99 \mathrm{Tc}$ distribution, releases from La Hague can be directly associated with the inventories of radioactivity measured in the southern North Sea. The average transit time of waters flowing from la Hague to the Strait of Dover is estimated as 110 to 152 days, and 170-250 days for the section between the Strait of Dover and the Skagerrak.

The numeric model developed to calculate long-term trajectories and dispersion of radionuclides into the Channel has been first validated using radioactivity measurements all over the Channel (SALOMON and al., 1988). In a second step, it has provided informations for interpreting the 
FLUXMANCHE MAST 52 data in the Strait of Dover during 1990 - 1991, by simulating the evolution of ${ }^{125} \mathrm{Sb}$ activities week by week in the waters flowing in the center of the Dover Strait.

Transit times along the coastal pathway of the Eastern Channel Measurements at station 6, in the coastal flow, continued after November 1991 along the neighbouring French coastline, show a maximum activity in November (figure 11), leading to an estimate of 6 months for the coastal transit. The study of the transfert of the winter 1986-1987 signal as indicated a value of 7 months for this coastal transit (GUEGUENIAT and al., 1993). In this case the maximum concentration of $125 \mathrm{Sb}$ at the begining of the transit correspond in time to the maximum monthly release which is observed in January 1987. In effect the water fluxes $\left(\mathrm{m}^{3} \mathrm{~s}^{-1}\right)$ during the pulse period were. SALOMON and al. (under press): 157 in November 1986, 120 in December 1986, 58 in January 1987, 135 in February 1987, 132 in March 1987. Consequently the maximum of the pulse is very clearly identifiable in the environment: a maximum in the release coïncide with a minimum is the water-fluxes. With this new information concerning th water fluxes it is possible now to undertake an overall re-interpretatio of previous data obtained in the Channel and North Sea.

\section{Conclusion}

In the present study, it is shown that soluble radionuclides introduced into the central Channel by the nuclear fuel reprocessing plant at La Hague are transfered towards The Strait of Dover in a time which varies between 4 and 7 months, depending on the route taken. The shortest transit time corresponds to a rapid pathway through the central Channel and the longest time to an indirect route via inshore waters, both are deduced from the hydrodynamic model. By an another way it has been demonstrated that the celerity at which the signal emitted at Cap de la Hague moves toward the 
Strait of Dover, and its intensity are also highly dependent on meteorological conditions, especialy thoses prevailing at the moment of the discharge.

As a consequence, a peak of nuclear activity in marine waters, even in the vicinity of the outfall, does not necessarely coincide with a peak in the discharges. Time series analysis in 1991 shows that a time shift may result, of the order of one month, for the transit from Cap de la Hague to the Strait of Dover.

These basic parameters may be taken into account by an advection dispersion numerical model. An hydrodynamic model is thus of utmost interest, at least for interpretation of wide measuring campaigns done through the North Sea. We may for example connect the spatial variations of the activity recorded along the spatial axis, to the time series computed in the Strait of Dover.

Such data analysis and interpretation, based on numerical simulation, have to be generalized in near future. It will be the case in the future for other radionuclides such as $99 \mathrm{Tc}, 90 \mathrm{Sr}, 106 \mathrm{Ru}$.

\section{Acknowledgement}

The present work was supported by the EEC Marine Science and Technology Programme, MAST 0053-C 


\section{References}

BAILLY du BOIS P., SALOMON J.C., GANDON R., GUEGUENIAT P. 1994

A quantitative estimation of English Channel water fluxes into the North Sea based on radiotracers distribution from 1987 to 1992.

Journal of Marine Systems, this volume.

GANDON R. and GUEGUENIAT P. 1992

Preconcentration of ${ }^{125} \mathrm{Sb}$ onto $\mathrm{MnO}_{2}$ from seawater samples for gamma-ray spectrometric analysis.

Radiochimica Acta 57,159-164.

GUEGUENIAT P., GANDON R., BARON Y., SALOMON J.C., PENTREATH J., BRILINSKY J.M., CABIOCH L. 1988

Utilisation de radionucléides artificiels $\left({ }^{125} \mathrm{Sb}-{ }^{137} \mathrm{Cs}-{ }^{134} \mathrm{Cs}\right)$ pour l'observation des déplacements des masses d'eau dans la Manche.

Radionucleides: a tool for oceanography. Cherbourg 1-5 juin 1987. Ed. Guary J.C., Guéguéniat P., Pentreath R.J.; Elsevier Applied Science Publishers, LONDON-NEW YORK pp. 260-270.

GUEGUENIAT P., SALOMON J.C., WARTEL M., CABIOCH L., FRAIZIER A. 1993

Transfer pathway and transit time of dissolved matter in the eastern English Channel indicated by space-time radiotracers measurement and hydrodynamic modelling.

Estuarine, Coastal and Shelf Science vol. 36, pp. 477-494. 
SALOMON J.C., GUEGUENIAT P., ORBI A., BARON Y. 1988

A lagrangian model for long term tidally induced transport and mixing. Verification by artificial radionuceide concentrations.

Radionucleides: a tool for oceanography Cherbourg 1-5 juin 1987. Ed. Guary J.C., Guéguéniat P., Pentreath R.J.; Elsiever Applied Sciency, LONDONNEW YORK.

\section{SALOMON J.C., GUEGUENIAT P., BRETON M. 1991}

Mathematical model of ${ }^{125} \mathrm{Sb}$ transport and dispersion in the channel

Radionuclides in the study of marine processes. Norwich UK, 10-13 September 1991 ed. Kershaw, J.P. Woodhead, D.S. Elsevier Applied Science p. $74-83$.

\section{SALOMON J.C,BRETON.M,GUEGUENIAT.P.(under press)}

.Computed residual flow through the Strait of Dover.

Océanologica Acta, Vol 16, n 5-6 . 


\section{Figures captions}

1 Positions of the 6 standard FLUXMANCHE sites

2 Monthly releases of la Hague nuclear fuel reprocessing plant, ${ }^{125} \mathrm{Sb}$

3 Monthly releases of la Hague nuclear fuel reprocessing plant, ${ }^{90} \mathrm{Sr}$

4 Monthly releases of la Hague nuclear fuel reprocessing plant, ${ }^{137} \mathrm{Cs}$

5 Distribution of ${ }^{125} \mathrm{Sb}$ activity in the central and eastern Channel during june 1986 (in $\mathrm{Bq} / \mathrm{m}^{3}$ )

6 Distribution of ${ }^{125} \mathrm{Sb}$ activity in the eastern Channel and south of North sea during january 1992 (in $\mathrm{Bq} / \mathrm{m}^{3}$ )

7 Simulation of permanent discharge (10 $000 \mathrm{GBq} / \mathrm{month})$ at la Hague (in $\left.\mathrm{Bq} / \mathrm{m}^{3}\right)$

8 Sketch map showing different transfer mechanisms for radiolabelled water discharged from the nuclear fuel reprocessing plant at la Hague. Bold arrows indicate the rapid central route and dashed arrows indicate the slow coastal route towards the entry to the North Sea

9 Variations of the concentrations of ${ }^{125} \mathrm{Sb}$ in the Strait of Dover measured at the six standard FLUXMANCHE sites

$10{ }^{125} \mathrm{Sb}$ normalized monthly releases fluxes in 1991 (percentage of the maximum value), compared to the non-normalized values (percentage of the maximum value)

11 Estimations of transit times from the la Hague area to the Strait of Dover through measurements of ${ }^{125} \mathrm{Sb}$ activities in the strait (SD : dashed lines, percentage of their maximum value) compared with normalized releases at la Hague (continuous line, also percentage of their maximum value)

12 Comparison between weekly calculated (diagram) and measured (dots) activities of ${ }^{125} \mathrm{Sb}$ in the central waters of the Strait of Dover 